\title{
Mustafazade A.I.`
}

DOI: 10.25108/2304-1730-1749.iolr.2017.53.99-114

\section{Some issues of the establishment of medical law as a new, independent field of law in Azerbaijan}

\begin{abstract}
It is considered an activity of the state on protection and strengthening of health protection of citizens. There is emphaside that an effective fulfilling of this activity depends directly on comprehensive legal regulation of public relations in this sphere. It notes that presently the legal norms in an area of public health are segmental and deprived the systematic order, as result, there is absent the unfied legal act, which might be fulfilled the basic function on this branch. It is pointed out the necessity to adopt an appropriate legal act on health protection of sitizens and establish the self-titled legal branch (medical law). Analysis of medical law formation as law's branch is made. It is summarised that medical law as an independent and comprehensive legal branch is a set of legal norms that regulate the relationships arising at organisation of medical process, strengthening and protection of public health.
\end{abstract}

Keywords: health protection of citizens; health care; normative legal act; medical law; legal regulation.

The importance and multi-aspect of the issue of health protection of citizens entails an increase in the number of scientific fields dealing with health research.

Legal science also plays an important role in the study of this issue. Strengthening population health, reducing illness, disability and mortality, increasing the quality and accessibility of medical services is one of the main

\footnotetext{
- Mustafazade Aytan Inglab qyzy - Doctor of Law, Director of the Intitute on Law and Human rights of ANAS, Member of the Parliament of Azerbaijan Republic (Azerbaijan). E-mail: info@human.science.az
} 
functions of each social democratic and legal state. Effective implementation of above-mentioned functions depends directly on the full legal framework of public relations in this area. The right to health and medical care is reflected in both national and international legal acts, is one of the fundamental rights of every human being without distinction of race, religion, political belief, economic or social condition.

Currently the human health protection through the complex legal regulation, the creation of an effective framework for the protection of human and civil rights and freedoms in this field is one of the pressing issue.

The emergence of new and modern diagnostic and treatment methods in the field of medical activity contributes to the necessity of the development of legal bases, the improvement of medical legislation, theoretical and practical solution to the problems arising in this field.

Now healthcare-related legal norms are dispersed, unsystematic, chaotic and distorted, and there is no single normative legal act that can act as a baseline in this field. Increasing the importance and quantity of the legislation on the health protection of the population shows the topicality of creation a single normative legal act, as well as the issue of the same legal field (medical law).

The scale, complexity and importance of public relations regulated by the norms of medical law allow it to be formed as an independent legal field. Some authors use the term "biomedical law" as the scope of the issues to be regulated by the rules of medical law significantly expanded (biosafety, molecular medicine, genetic engineering, cloning, the legal status of the human embryo, surrogate motherhood, transplantation, euthanasia, etc.) [3, p. 59].

Sometimes it is indicated that taking into account the peculiarities of legal relations, it would be important to replace all the terms like "health law", "the right to health protection", "medical law" with the term "the right to health protection" or "health right" [2, p. 3-8]. 
In the literature, any legal field is considered in three terms: legal field, legal science, and subject. With regard to medical law, this can be expressed as follows: Medical law is the body of laws identified and sanctioned by state or international organizations regulating relations in health and medical practice. Medical law science is a science about the legal regulation of health, medical activity and its subject is medical law. Medical law as a teaching subject incorporates a comprehensive set of knowledge about legal field and legal science [1, p. 29].

The process of formation of medical law as an independent legal area began with the second half of the $20^{\text {th }}$ century. Initially, the right to health was part of international law. A decision to study the problems of international medical law was made in 1953, and the International Committee on Medical Law was established in 1956.

The founder of the social security law, V. Andreev, for the first time proposed the idea of separating the right of medical science as an independent field. The prominent scientist has developed the theory of the subject and method of medical law. At a conference in Prague in 1977, it was deemed necessary to establish a separate legal field - medical law.

Most of the norms of practical importance for participants of public relations related to medical activity in the Soviet period were ethical. In the 90's, the situation changed. In the 1990's, the adoption of a large number of legislative acts aimed at the legal regulation of public relations in the field of protection of human and civil rights entailed the formation of the same legal framework. This increased the social demand for the right to health, as a new field of law.

It is justified that there is a comprehensive law, along with the traditional law in legal science. While the traditional law area has a predetermined unity, the comprehensive law has not such unit because it regulates various types of public relations. The comprehensive law field uses a number of legal arrangements of 
main fields. The structure of the comprehensive law field is formed by the norms of other (basic, traditional) fields of law.

Medical law is a field of comprehensive law. Because the health protection of citizens and the legal regulation of public relations on medical aid are provided by the norms of different legal fields - constitutional, civil, administrative, social, criminal, family, other legal fields. The right to health and the right to receive medical care are determined by the norms of the Constitution (Article 41 of the Constitution of the Republic of Azerbaijan). There is administrative, civil and criminal liability for damage to health. Private entrepreneurship activity in the field of health protection of citizens (providing medical services, medication, sanitary and epidemiological safety etc. without establishing legal entities and various forms of ownership) is primarily regulated by civil law norms, but also are significantly limited by administrative, customs, tax law.

As we can see, there is an abundance of norms currently regulating relations in the field of health, which has been identified in various legal acts and belonging to various fields of law.

Medical law acts as a comprehensive law, incorporating different institutes of different legal fields. Regulation of relations in the field of healthcare with the norms of different legal fields, allows to refer medical law to comprehensive law.

Y. D. Sergeyev and A. Makhov explain medical law as a system of legal norms regulating public relations in the field of health protection and healthcare, as well as in the process of activity and development of the health sector. These authors point out that the right to medical care should be distinguished as an independent legal area on the following basis: 1) the public need and public interest in the independent legal regulation of health - one of the fields with the social and political significance for each individual, society and the state; 2) the existence of an independent legal regulation; 3) the need for special reconciliation 
methods of legal regulation; 4) the need for special legal sources; 5) Only special concepts and categories inherent in this field of law [3, p. 51-52].

The increasing legal and social importance of medical law is related to the fact that public relations governed by this area are of social importance.

For the purpose of implementing the goals and objectives of the society and the state with the help of legal regulation, they are distributed and constrained in a number of areas of national law. The goal of protection and strengthening the health of citizens and society as a whole is within the scope of medical law.

A number of concepts that are reflected in legislative acts, such as medical intervention, health care system, and others are not specifically investigated within other legal fields. This fact shows the importance of the development of medical law as an independent legal field.

All above mentioned, including the social needs, the subject of independent legal regulation, only the concept and category apparatus that are typical of medical law confirms the full and complete existence of objective principles for the grouping of norms regulating relations in the field of healthcare and medical practice today.

Medical law acts as a part of special law. Because relations between healthcare providers, i.e healthcare institute and consumers of the service, i.e the patient, are regulated by the rules of special law. On the other hand, it acts as an integral part of general law. Because some subjects of the medical law are assigned certain functions and duties by the state (for example, medical examination and treatment, vaccination, etc.).

There have been several approaches to whether medical law is a field of law. According to the first approach, medical law is a semi-part of social security law. Representatives of the second approach consider medical law as a complex legislative framework. Supporters of the third approach, however, rightly consider medical law as an independent comprehensive law. 
Medical law can be distinguished as an independent legal field for the following reasons: the existence of a particular concept and category specific to that field of law; the scale, complexity and importance of public relations regulated by medical law; the presence of public necessity and public interest in the legal regulation of health; the existence of an independent legal regulation, although not identical; to have legal regulation methods, typical for comprehensive law fields (medical law uses basic methods of legal regulation as it contains general and specific law); formation of a rich legislative framework (legal sources) in this area.

The existence of excessive health and healthcare norms, eventually, creates new qualities in matters of its legal regulation, methods, principles and mechanisms, which in turn implies the existence and development of a new field of law. The main purpose of medical law is to regulate the numerous and varied relations in the field of health. To achieve this goal, the establishment of favorable conditions for effective health care, ensuring the rights, freedoms and legitimate interests of citizens in the field of health, the establishment of effective legal regimes for the regulation of separate types of medical activities, the scientifically justified system of health organization and management in the country installation and solving such other issues is absolutely necessary.

Medical law as a field of comprehensive law differs from the main legal fields by the following characteristics:

- absence of a common identical regulation subject;

- totality of a system of legal norms derived from different legal fields;

- absence of common, systematized, normative-legal act that constitutes the basis of medical legislation;

- the use of legal regulation methods derived from major, traditional law field.

Medical law interacts with constitutional, civil, social, family, administrative, financial, criminal, civil, procedural, criminal and procedural and other fields of law and adopts certain legal categories and provisions from those jurisdictions. 
In the past few years in Azerbaijan development of legislation in the field of social rights of citizens, medical and legal relations in the society, adoption of a number of new laws in various spheres of law stipulate the formation of a clear system of relations within the framework of a specific new branch of law. The development of medical law in Azerbaijan is a natural consequence of the evolution of legislation and law as a science.

Thus, medical law as an independent and comprehensive law is a set of legal norms in the health protection of citizens, the provision of medical care, the organization of the medical diagnostic process, the medical and preventive and sanitary-epidemiological measures in the process of establishing, functioning and developing the health care area, as well as in the regulation of the relations arising during the organization of sanatorium resort treatment.

\section{References}

1. Ivannikov I.A., Rubanova N.A. Meditsinskoe pravo. Uchebnoe posobie [Medical law. Teaching aid]. Moscow, 2008, 208 p.

2. Sergeev Yu.D., Milushin M.I. O teoreticheskikh osnovakh i kontseptsii natsional'nogo meditsinskogo prava [On theoretical outlines and concepts of national medical law]. Meditsinskoe pravo [Medical law], 2003, no. 3, pp. 3-8.

3. Sergeev Yu.D., Mokhov A.A. Osnovy meditsinskogo prava Rossii. Uchebnoe posobie [Outlines of Medical law of Russia. Teaching aid]. Pod red. Yu.D. Sergeeva [ed. by Yu.D. Sergeev]. Moscow, 2007, 306 p. 